Article

\title{
Green Infrastructure and Biophilic Urbanism as Tools for Integrating Resource Efficient and Ecological Cities
}

\author{
Giles Thomson ${ }^{1,2, *}$ and Peter Newman ${ }^{2}$ \\ ${ }^{1}$ Department of Strategic Sustainable Development, Blekinge Institute of Technology, 37150 Karlskrona, Sweden; \\ E-Mail: grt@bth.se \\ ${ }^{2}$ Curtin University Sustainability Policy Institute, School of Design and the Built Environment, Curtin University, Perth, \\ WA 6102, Australia; E-Mail: p.newman@curtin.edu.au \\ * Corresponding author
}

Submitted: 7 September 2020 | Accepted: 30 November 2020 | Published: 26 January 2021

\begin{abstract}
In recent decades, the concept of resource efficient cities has emerged as an urban planning paradigm that seeks to achieve sustainable urban environments. This focus is upon compact urban environments that optimise energy, water and waste systems to create cities that help solve climate change and other resource-based sustainability issues. In parallel, there has been a long-standing tradition of ecological approaches to the design of cities that can be traced from Howard, Geddes, $\mathrm{McHarg}$ and Lyle. Rather than resource efficiency, the ecological approach has focused upon the retention and repair of natural landscape features and the creation of green infrastructure (GI) to manage urban water, soil and plants in a more ecologically sensitive way. There is some conflict with the resource efficient cities and ecological cities paradigms, as one is pro-density, while the other is anti-density. This article focusses upon how to integrate the two paradigms through new biophilic urbanism (BU) tools that allow the integration of nature into dense urban areas, to supplement more traditional $\mathrm{GI}$ tools in less dense areas. We suggest that the theory of urban fabrics can aid with regard to which tools to use where, for the integration of $\mathrm{GI}$ and $\mathrm{BU}$ into different parts of the city to achieve both resource efficient and ecological outcomes, that optimise energy water and waste systems, and increase urban nature.
\end{abstract}

\section{Keywords}

biophilic urbanism; ecological cities; green infrastructure; resource efficient cities; urban fabric theory; urban planning

Issue

This article is part of the issue "Urban Planning and Green Infrastructure" edited by Paul Osmond (University of New South Wales, Australia) and Sara Wilkinson (University of Technology Sydney, Australia).

(C) 2021 by the authors; licensee Cogitatio (Lisbon, Portugal). This article is licensed under a Creative Commons Attribution 4.0 International License (CC BY).

\section{Introduction}

The numerous benefits of urban nature, such as ecosystem services (e.g., urban cooling, flood mitigation), increased biodiversity, health and economic benefits are well established in the literature (Brink et al., 2016; Hansen et al., 2015; Mcdonald, Beatley, \& Elmqvist, 2018; MEA, 2005). However, many urban dwellers do not live close enough to urban nature to receive these benefits (Mcdonald et al., 2018), the challenge remains where and how to (re)integrate nature into cities, especially in large and densely developed cities where little space can be found. In dense urban areas where undeveloped land can be found, justifying its preservation for urban nature may be difficult to argue because pressure is high for other uses, e.g., affordable housing, parking or local job creation through commercial buildings. This is made harder when the global and local agenda for dealing with major issues like climate change is seen to need increases in density, not decreases (Intergovernmental Panel on Climate Change [IPCC], 2018; Newman, Beatley, \& Boyer, 2017; United Nations, 2017). Limited urban space has traditionally meant reduced integration of ecosystem services. Similarly, despite considerable literature 
extolling the benefits of ecosystem services, uptake in urban planning discourses and practice is slow, highlighting the need for systemic approaches for integrating urban nature within urban planning (Hansen et al., 2015). So, how can the urban planner address the need to increase urban nature in cities while also addressing the need for dense urbanism?

This article describes how there are new tools that can help with this resolution. It suggests that we need to begin by recognising that there are two major urban planning paradigms for how cities must face the 21st century-ecological cities and resource efficient cities-and if they are not understood as both having legitimacy in urban planning, then it will be difficult to resolve some of their inherent conflicts. The article suggests that there is a fundamental issue about urban density that leads to their conflict. It seeks to resolve this conflict and show how ecological cities and resource efficient cities can be better integrated to create more complete solutions to 21st century urban problems through the adoption of the two tools of green infrastructure (GI) and biophilic urbanism (BU). Thus, it is an early attempt to help resolve the conflict that arises between the need for density to optimise circular urban systems within resource efficient cities, and the need to find space to maximise urban nature in ecological cities.

The article aims to show how the theory of urban fabrics (Newman, Kosonen, \& Kenworthy, 2016) can offer a useful lens to assist urban planners and policy makers when considering how, and where, to integrate urban nature into different parts of the city using the two tools. The approach involved reviewing current and classic literature on ecological cities and resource efficient cities. Subsequently, the theory of urban fabrics was used to begin to develop a typological categorisation for integrating nature into urban areas based upon urban morphology and density. The key is to begin by recognising that there are different urban fabrics within a city, therefore rather than having a simple manual for urban nature integration across a whole city, an urban fabric typology will allow for a nuanced response to urban nature integration into different parts of a city. This article represents a first step to integrate several concepts in the hope to show that planners should not only consider urban nature within designated open space, gardens or residual land, but that the possibility also exists to retrofit urban nature into established and dense urban areas.

\subsection{Paradigm 1: Ecological Cities}

There exists a long history of proponents for the integration of nature into cities, below we introduce several notable names, including Howard, Geddes, McHarg and Lyle who helped establish the paradigm of ecological cities.

A little over 100 years ago Ebenezer Howard's concept of the 'garden city' became highly celebrated as a city planning concept. At its essence it takes the best elements of town, and country, in a new typology towncountry. Town-country blends the beauty of nature with the social opportunity of the city, at least that was the promise. Howard outlined his vision for the ideal garden city as a highly prescriptive modular, symmetrical urban structure of separated land uses that should house 32,000 people across 9,000 acres (Howard, 1902). Despite being hugely popular the ideal plan was never fully realised at the city-scale, rather it inspired many smaller subdivisions in the UK and around the world, as neatly designed subdivisions with housing, local shops, geometric street patterns and abundant urban greenery. Equally relevant as the planning principles of the garden city movement, are those socio-technical drivers that led to its popularity. Howard's ideas were born in the Victorian era. The timing is significant, as this was a period where uncontrolled coal burning to fuel industry and warm households led to blackened skies in and around urban areas, creating the 'smoke fiend' (Howard, 1902). Howard's vision was for smokeless cities, that combined the benefits of urban life and work with the access to nature found in the countryside. The vision of low density green suburbs was born in this era (Kostoff, 1991; Mumford, 1961).

Patrick Geddes was a contemporary of Howard, who took a more scientific approach to the incorporation of nature into cities. In the late 19th century and early 20th century he described the intersection between the human systems of town planning and the natural systems of ecology and geomorphology. Geddes lamented that the loss of "natural conditions" and those "great open spaces...[the] lungs of life, are already all but irrecoverable" (Geddes, 1915, p. 34). Geddes work was highly influential upon lan McHarg, the landscape architect who in 1969 wrote the influential publication Design with Nature, in which he outlines an ecological view to accommodate natural conditions in areas of urban expansion. McHarg's 'sieve mapping' approach starts by identifying the most valuable landscape elements as a 'landscape footprint,' i.e., an area to be preserved; with the residual low ecological value areas designated as the 'urban footprint,' i.e., an area to be developed (McHarg, 1969). McHarg, was not known for his love of cities, but he outlined a systematic approach to preserve those 'irrecoverable' spaces, as Geddes called them, from urban displacement. In the 1980s and 1990s another landscape architect, John Lyle, drawing upon environmental elements of nature restoration, developed the notion of 'regenerative design' (Lyle, 1996). Lyle's approach went further than McHarg's conservation of landscape footprint, seeking instead to regenerate the ecological function of degraded landscapes. Lyle's work was largely landscape based, but regenerative design is increasingly applied to the restoration of degraded urban areas (Girardet, 2010, 2015; Mang \& Reed, 2012). Geddes lamented the loss of access to nature, but McHarg and Lyle show how it is possible to preserve and regenerate ecological functions in urban 
areas. Collectively the works of these early thought leaders set the conceptual groundwork for the current proliferation of writing about nature in the city.

Cities are designed landscapes and human settlements are typically sited in response to natural conditions i.e., bioregional context, topography, hydrology, soils and so on, but as the city grows the artificial subsumes the natural. In many of the world's larger cities scant evidence of these original natural conditions remains. A consequence has been the general decline in urban dwellers' everyday interaction with nature, as well as loss of the many ecological functions of those natural features. This trend has been observed across the globe (Soga \& Gaston, 2016), in response, some authors have highlighted the need to re-connect urban dwellers with nature (Andersson et al., 2014; Samuelsson, Colding, \& Barthel, 2019). Scientists have been calling for some time for the urban narrative to change away from the perception of city-nature duality towards a greater integration of nature (Grimm et al., 2008; MEA, 2005). Increasingly city and regional planners are also recognising that better integration of natural systems is necessary (Newman \& Jennings, 2008). However, to create space for nature, cities should necessarily spread out. Inspired by Raymond Unwin's (1912) garden cities pamphlet, the early motto of the Town and Country Planning Association was "nothing gained by overcrowding." But how is this done when the other major paradigm, resource efficient cities, appears to be working against this by promoting density?

\subsection{Paradigm 2: Resource Efficient Cities}

From the 1940s on, suburbs based around automobile dependence absorbed huge amounts of land as they rolled across the landscape leaving little of the natural features behind. The first studies on sustainability in cities showed that the low-density car-based suburbs were extremely high in resource consumption (Newman \& Kenworthy, 1989, 1999). This moved into an era of urban planning to try and reduce car dependence through increased density, particularly around transit systems, to reduce travel demand (Calthorpe, 2010).

'Urban regeneration' is a process that the modern planning profession has used for well over three quarters of a century-typically to reverse the physical and social decline of an urban precinct via redevelopment (Roberts, Sykes, \& Granger, 2016); but increasingly there is an ecological component to regeneration, with a planning intent to create a significantly smaller ecological footprint as well as higher amenity through more equitable access to urban jobs and services (Newton \& Thomson, 2016; Rees \& Wackernagel, 2008).

At its essence, resource efficient cities is a process whereby urban areas are designed to reduce adverse environmental impact between the city and the ecosystems from which it draws its resources (Girardet, 2010, 2015; Hes \& du Plessis, 2014). Delivering resource effi- cient cities is an integrated process involving energy, water, waste within any urban area, but has mostly focussed on how it can make cities into being more regenerative of the atmosphere as climate issues have become a bigger and bigger focus (Thomson \& Newman, 2016, 2018a). Thus, the resource efficient city paradigm aims to achieve more than conventional city planning driven by real estate markets or occasionally social renewal.

But significant research in the past 50 years indicates that resource efficiency potential is greatest in compact cities (Creutzig et al., 2018; Neuman, 2005); this view is supported by the IPCC's assessment of cities and their policies to help shape a decarbonised future (IPCC, 2018; Seto et al., 2014). Thus, the notion of higher density to enhance resource efficient outcomes may in fact be in conflict with major elements of the low-density agenda within the ecological cities paradigm.

\section{The Clash Between the Two Paradigms}

Both the ecological and resource efficient urban planning paradigms have legitimate claims to being powerful guidance systems for planning the cities of the future. Resource efficient cities seek to create dense centres of development that can create more renewable energy than consumed, as well as other environmental improvements, i.e., they are compact. Compact cities also minimise encroachment on ecologically or agriculturally important land on city fringes (Folke, Jansson, Larsson, \& Costanza, 1997). However, compact city and urban infill agendas have their own limitations, and a long standing criticism of dense cities has seen the disappearance of gardens, reduced urban ecology and other ecosystem services within cities as a result of urban intensification (Breheny, 1997). The pressure to regenerate cities means that redevelopment can indeed conflict with ecological outcomes.

When some planners want to see increased urban density in areas to improve the sustainability and resource efficiency potential of a city (Newman \& Kenworthy, 1999), other planners object on the basis of ecological disturbance and loss of ecological functions (Lo, 2016). The next section describes how urban planning can possibly reconcile this apparent conflict using some new tools that are increasingly available to cities around the world.

\section{Tools for Integrating the Planning of Ecological Cities and Resource Efficient Cities}

Two tools will be outlined that can help planners integrate both the ecological and the resource efficiency approach within cities: $\mathrm{GI}$ and $\mathrm{BU}$.

\subsection{Green Infrastructure (GI)}

GI can be considered a counterpoint to the 'grey infrastructure' of roads, buildings, car parks and other impervi- 
ous hardscapes that typify industrial cities of the Modern era. GI can be defined as a:

Strategically planned network of natural and seminatural areas with other environmental features designed and managed to deliver a wide range of ecosystem services such as water purification, air quality, space for recreation and climate mitigation and adaptation. This network of green (land) and blue (water) spaces can improve environmental conditions and therefore citizens' health and quality of life. (European Commission, 2013, p. 3)

\subsection{Biophilia and Biophilic Urbanism (BU)}

Biophilia was defined by Wilson (1984, p. 1) as "the innate tendency to focus on life and lifelike processes." Wilson was an ecologist whose special insight was that this biophilic propensity developed as part of evolutionary survival, so it remains with humans in their daily lives, even in modern cities (Newman, 2020). Biophilic design has become a major social movement within city policy and practice (Beatley, 2011; Kellert, 2012). There is now a Biophilic Cities Network with membership across the globe as they work together showing how cities can integrate nature. This inevitably involves town planning and previous studies describe biophilic city design elements across scales, from building, block, street, neighbourhood, community, and region (Beatley \& Newman, 2013).

BU has developed a series of science and engineering approaches that mimic natural systems within denser urban environments. These emerging BU approaches mean urban greenery is no longer limited to undeveloped land, but can also be integrated on, in and over built structures, for example as integrated green walls and green roofs as biophilic facades on buildings (Figure 1). Similarly, integrated water management approaches allow for local infiltration, rather than traditional grey infrastructure approaches that channel or pipe water away from urban areas and into remote detention ponds, rivers or the sea (see Beatley, 2011).

$\mathrm{BU}$ has been increasingly applied to the densest parts of cities with some success such as in Singapore (Newman, 2014). While the planning concepts of compact resource efficient cities versus spreading ecological cities appear to clash, they can be reconciled through GI integration in dense urban areas using BU approaches. BU provides new opportunities for urban ecology to become a crucial element of the resource efficient cities approach. $\mathrm{GI} / \mathrm{BU}$ has the potential to deliver a range of cross cutting benefits such as food production, clean water and air, reduced storm water flows, urban cooling (Pauleit, Zölch, Hansen, Randrup, \& Konijnendijk van den Bosch, 2017), just as the ecological cities paradigm has always suggested but it can now be done in dense areas as well as low density areas.

Section 4 describes how urban planning can potentially resolve the two paradigms through integration, by utilising the spatial characteristics of different urban fabrics, i.e., by facilitating traditional GI approaches in less dense urban fabrics, and BU approaches in denser urban fabrics.

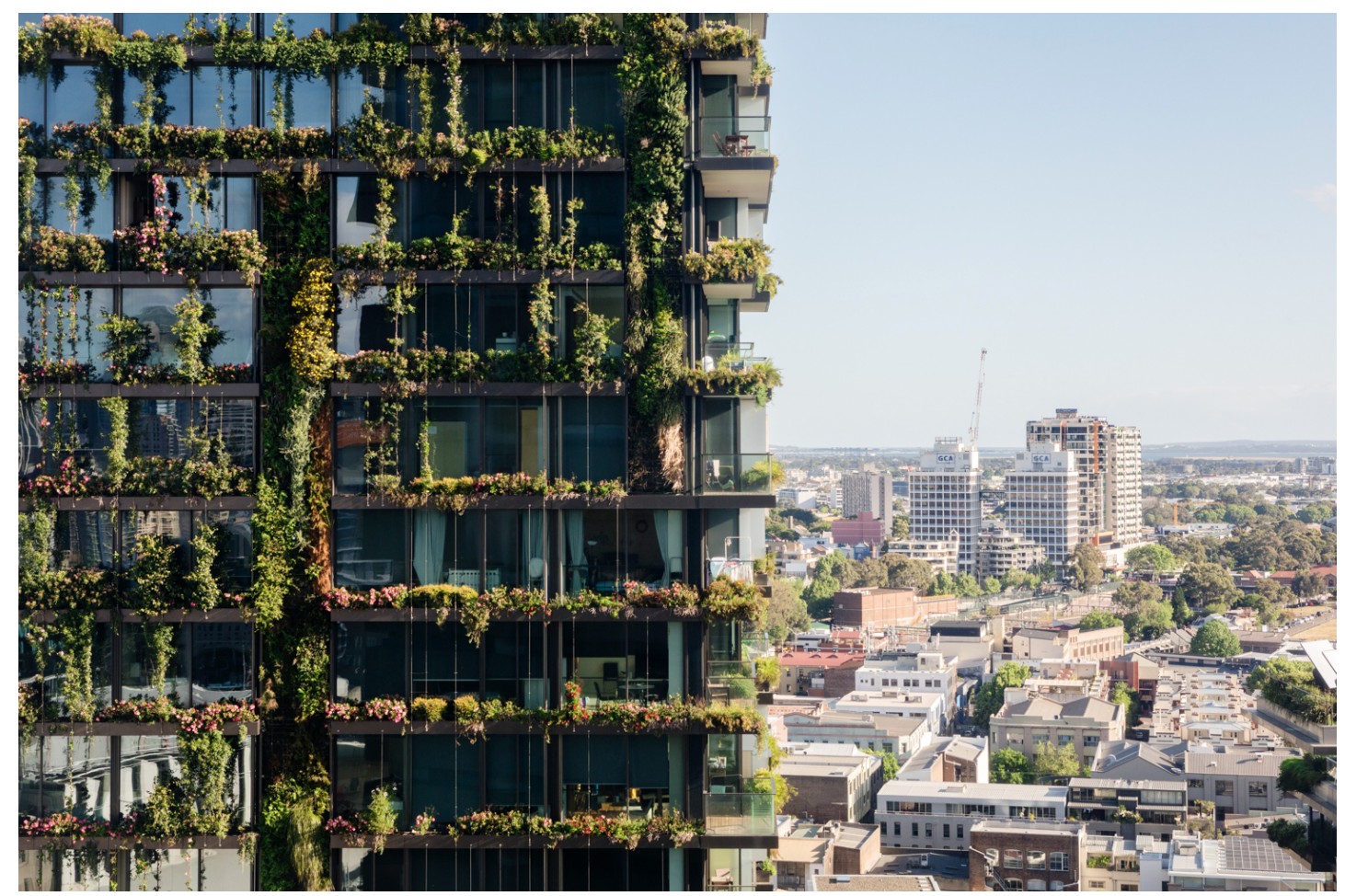

Figure 1. 'Central Park' Sydney, Australia: Biophilic façade. Source: Katherine Lu. 


\section{The Theory of Urban Fabrics: Integrating Resource Efficient and Ecological Cities}

\subsection{Theory of Urban Fabrics}

Urban fabrics are products of transport-related lifestyles and functions that have needed certain physical elements and environments to enable them (Newman \& Kenworthy, 2015; Newman et al., 2016). Each urban fabric has a particular set of spatial relationships (Figure 2), building typologies and specific land-use patterns that are based on their transport infrastructure priorities.

All cities are made from a mix of urban fabrics each with different characteristics, including different opportunities or limitations for the incorporation of natural systems using $\mathrm{GI}$ and $\mathrm{BU}$. Recognising this allows for a more nuanced planning policy response that can potentially resolve the conflict between the two planning paradigms. This holds true for new urban development and perhaps more critically, for urban retrofits. The four dominant urban fabrics roughly correspond to major sociotechnical stages in industrial society that are reflected in urban form and which continue to be regenerated in each new period of history (Newman, 2020).

\subsubsection{Walking Urban Fabric}

Prior to the 1850 s nearly all cities were walking cities, characterised by dense, mixed-use areas of generally more than 100 persons per hectare. These are the oldest typology, this fabric dominated until the 1850s. Many modern cities, are built around a nucleus of an older walking city, but they struggle to retain the walking urban fabric due to the competing urban fabrics especially automobile city fabric which now overlaps it, but there is a global movement to introduce more, or regenerate old walking urban fabric (Gehl, 2010; Matan \& Newman, 2016; Newman \& Kenworthy, 2015). The high density of walking urban fabric means that there is usually little space available for traditional GI outside of formal open space or parklands.

\subsubsection{Transit Urban Fabric}

Between 1850 and 1950, trains, followed by trams from the 1890s, extended the old walking city. This transit urban fabric takes the form of corridor development with typical densities between 35 and 100 persons per hectare, yet higher density walking fabric still remained around transit stops. The increased speed of transit allowed development to extend $20 \mathrm{~km}$ or more from the centre. There is a growing push for sustainable cities to reinstate or introduce, dense transit corridors to move large volumes of people and alleviate congestion, this is particularly advanced in Asian cities (Gao, Newman, $\&$ Webster, 2015). Density remains high in transit urban fabric, but the slightly lower densities mean it is usually less constrained in terms of Gl opportunity than walking urban fabric.

\subsubsection{Automobile Urban Fabric}

From the 1940 s onward, western cities, and increasingly the world's cities, have been dominated by low-density automobile urban fabric. The term 'automobile dependence' was developed in the 1980s to express how cities were increasingly being built around the car (Newman \& Kenworthy, 1989). Automobile fabric is composed of low-density suburbs (population densities of less than 35 persons per hectare), due to the flexibility and speed (average $50-80 \mathrm{~km} / \mathrm{hr}$ on uncongested roads) of automobiles to spread over considerable land area. Automobiles

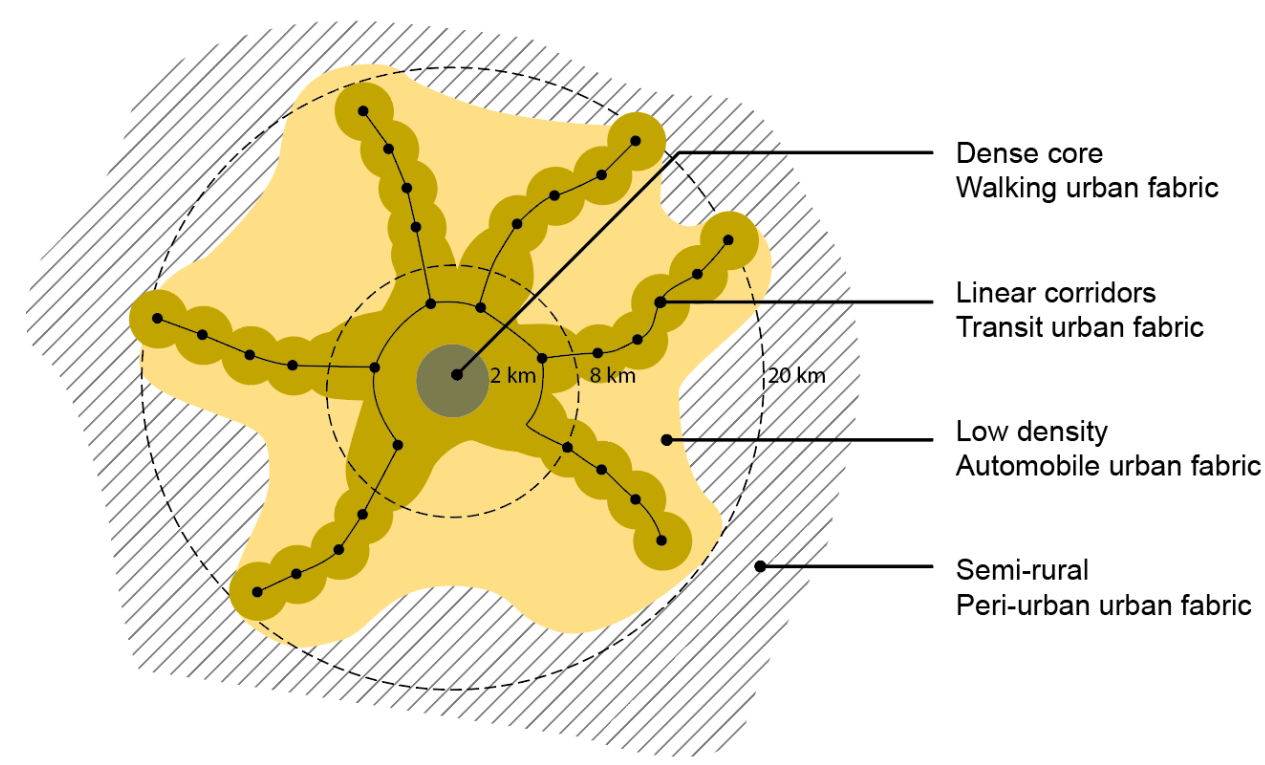

Figure 2. Conceptual city plan illustrating the spatial arrangement of the four urban fabrics relative to one another. Source: Adapted from Newman and Kenworthy (2015). 
service dormitory suburbs, and most dwellings are villas set in gardens, usually served by freeways rather than trains. "Human society and the beauty of nature are meant to be enjoyed together" according to Howard (1902, p. 17), private vehicles and the mobility they offer, were responsible for unlocking vast expanses of land to enable many to access this reality in the suburbs. But increasingly, as the limits to suburban sprawl are realised in larger cities, compact city policies lead to ever smaller plots of infill development that erases the garden qualities of the suburbs, with many unbuilt areas 'hardscaped' to support vehicle infrastructure e.g., setbacks, driveways and car parking (Breheny, 1997; Hall, 2007; Newton \& Glackin, 2014) - not always with land allocated for natural systems. Car dependent cities (dominated by automobile fabric) have around $30 \%$ of their urban space in bitumen, with more than eight car-parking spaces per vehicle (Newman \& Kenworthy, 1999).

\subsubsection{Peri-Urban Urban Fabric}

Peri-urban areas have many of the characteristics of automobile urban fabric. Because peri-urban areas are the interface between urban and rural landscapes, land allotments tend to be larger, varying between suburban clusters and semi-rural landholdings. It is a zone of transition, where relatively cheap land is largely occupied by commuters, 'big-box' retail and some industrial activity, all connected to the urban centre via arterial roads and highways. Yet the peri-urban landscape tends to retain substantial remnant vegetation, cultivated lots and gardens (McKinney, 2006). As cities grow outwards these remnants are often displaced by more homogenous automobile urban fabric.

The limits of car dependent development models (e.g., automobile and peri-urban urban fabric) are now being recognised based upon the environmental (e.g., fuel use), economic (e.g., time and infrastructure costs) and social (e.g., congestion, social isolation) issues that result (Newman \& Kenworthy, 2015; Urry, 2004), and have driven a planning backlash toward compact cities and the current preference for urban infill (Thomson \& Newman, 2017). However, infill has its own limitations, not least the disappearance of gardens, but also the displacement of urban ecology and other ecosystem services that occur as more ground is taken over by development. Such losses are beginning to be measured as part of urban planning performance, especially for the urban heat island effect (Ding, 2019).

Urban fabrics are recognisable as urban morphological patterns of development within cities. They effectively represent an urban development intensity gradient, where the urban intensity is a function of the dominant transport pattern (Newman \& Kenworthy, 1989, 1999). Typically, urban greenery (outside formal parkland) is inverse to urban density. Peri-urban and automobile urban fabric have the greatest proportion of undeveloped ground and more potential for urban greenery, con- trasting with the denser walking and transit urban fabric with less undeveloped land available for introducing GI though this is not always the case as wealthy dense areas of cities are often heavily replete with street trees and small urban parks (Newman \& Kenworthy, 2015).

\subsection{Could GI and BU Integrate Ecological Cities and Resource Efficient Cities?}

If we overlook the idealised garden city plan and instead focus upon the conceptual principles, such as access to nature, nutrient cycling, local food production and other ecological principles, Howard's vision seems highly relevant today, even though the drivers for change may have shifted from repairing the social ills of smoky slums to addressing sustainability and resilience challenges. Clark (2003) provides a fascinating account outlining the conceptual and political foundations of Howard's vision and concludes that "Howard's work remains a model for a sustainable relationship with nature, as garden cities offer a possible direction on the route to creating a future in which human society and nature can successfully coevolve" (Clark, 2003, p. 96).

A vision for achieving this has been outlined in literature on biophilic cities (Beatley, 2009; Beatley \& Newman, 2013; Soderlund \& Newman, 2015), and socioecological urbanism (Marcus et al., 2019). But the challenge remains: how is it possible to reconcile growing demand for urban land and the need for compact ecoefficient sustainable cities and urban nature with its multiple ecosystem services? New science and engineering is creating more opportunities for $\mathrm{Gl}$ and $\mathrm{BU}$ to be built into the actual fabric of cities, not just the land between the built environment fabrics. Andersson et al. $(2014$, p. 450) note that "cities hold unexplored potential for new urban spatial designs that integrate ecosystem services in the built environment, for restoring degraded ecosystem functions through complementary designs of land uses and urban green structures." As we outline in the next sections, there is great potential for the (re)integration of $\mathrm{Gl}$ and $\mathrm{BU}$ into new and existing urban areas once planners recognise the availability of the new scientific tools and how to apply them in different parts of the city as the city is made up of different urban fabrics, each with different potential for using the new tools. Previous studies outlining urban fabrics (Newman, 2020; Newman \& Kenworthy, 2015; Newman et al., 2016; Newman, Thomson, Helminen, Kosonen, \& Terämä, 2019) emphasise urban structure and form, rather than $\mathrm{GI}$ and $\mathrm{BU}$. In the next section we describe how urban fabrics may be useful as a typological approach to aid planning decisions relating to integration of $\mathrm{GI}$ and $\mathrm{BU}$.

\section{3. $G I, B U$ and Urban Fabrics}

The $\mathrm{GI}$ and $\mathrm{BU}$ in different parts of the city will necessarily vary due to the different availability of space and the 
different value of land. Outside of the centrally planned regional open space structure, most $\mathrm{GI}$ is the result of thousands of micro scale decisions, as codified in planning regulations. The generic urban areas of built form, streets and infrastructure, those cellular pieces that collectively form the urban morphological patterns comprising the vast bulk of any city, i.e., the 'urban fabric,' are where urban planning is able to use these new tools.

Recognising that almost every city is made up of a range of urban fabrics, will help policy makers write supportive regulations to aid GI/BU uptake. Formalising such a process could incentivise and empower citizens and individuals to integrate much needed urban ecology, even in established areas. We provide some initial ideas relating to the type of approaches that can be used. Comprehensive policies of course must respond to the local bioregion, but the spatial characteristics due to land availability and development density are much more generalisable.

Figure 3 summarises the urban fabric characteristics, and key $\mathrm{Gl} / \mathrm{BU}$ opportunities and challenges for each. It indicates how planners and designers could develop a typological approach for urban nature interventions in any part of a city, by matching $\mathrm{Gl} / \mathrm{BU}$ responses to the relevant urban fabric.

Traditional GI, e.g., gardens, swales, wetlands that occupy undeveloped ground, will be most appropriate in low-density peri-urban and automobile urban fabrics. They are also the least technical and least expensive to deliver and maintain, though they cannot be neglected either. By contrast, in the denser walking and transit urban fabrics where space is limited, more technical $\mathrm{BU}$ approaches allow for the integration of green and blue infrastructure where previously it was not possible. $\mathrm{BU}$ innovations such as green roofs, green walls, engineered biofiltration strips and the like tend to cost more, but publicly delivered projects will benefit from higher land taxes per hectare, similarly private projects benefit from greater density with higher site yields allowing any additional costs to be ameliorated over multiple dwellings. Urban nature also increases property value (Colding \& Barthel, 2013; McDonald et al., 2016), so in

\begin{tabular}{|c|c|c|}
\hline Urban Fabric & Characteristics & GI / BU opportunities \& challenges \\
\hline Walking Urban Fabric & $\begin{array}{l}\text { - Central urban core } \\
\text { - Dense, mixed-use areas } \\
\text { - Generally more than } 100 \text { persons } \\
\text { per hectare } \\
\text { - Dense non-residential services in } \\
\text { close proximity to residential } \\
\text { population }\end{array}$ & $\begin{array}{l}\text { - Limited space for GI outside public } \\
\text { realm (e.g. parks and streets) } \\
\text { - Greatest GI opportunity in public } \\
\text { realm (e.g. biophilic streets, parks) } \\
\text { - Potential to incorporate BU in/on } \\
\text { private built form as green roofs, } \\
\text { green walls, detention basins etc. } \\
\text { - Higher tax revenue per hectare allows } \\
\text { higher public GI/BU budget for } \\
\text { projects/maintenance }\end{array}$ \\
\hline Transit Urban Fa & $\begin{array}{l}\text { - Typical densities between } 35 \text { and } \\
100 \text { persons per hectare } \\
\text { - Higher density walking fabric still } \\
\text { remained around transit stops } \\
\text { - Clusters of services at activity nodes }\end{array}$ & $\begin{array}{l}\text { - Fairly limited space for GI outside } \\
\text { public realm } \\
\text { - Moderate potential for GI/BU in } \\
\text { private realm e.g. gardens } \\
\text { - Linear corridors along transit routes } \\
\text { and biophilic streets } \\
\text { - BU in/on built form }\end{array}$ \\
\hline Automobile I & $\begin{array}{l}\text { - Low population densities of less than } \\
35 \text { persons per hectare } \\
\text { - Typically single dwellings on larger } \\
\text { blocks with gardens } \\
\text { - Monocultural land uses } \\
\text { - Sparsely distributed services }\end{array}$ & $\begin{array}{l}\text { - High potential for private on-plot GI } \\
\text { e.g. gardens } \\
\text { - The lower the density the greater the } \\
\text { private on-plot Gl opportunities } \\
\text { - Lower density areas have less land } \\
\text { tax per hectare therefore less income } \\
\text { for public GI projects projects/ } \\
\text { maintenance }\end{array}$ \\
\hline Peri-urban Urban Fabric & $\begin{array}{l}\text { - Very low densities on the urban } \\
\text { fringe } \\
\text { - Predominantly residential } \\
\text { development on large blocks } \\
\text { - Remnant fragments of cultivated } \\
\text { and ecological land } \\
\text { - Minimal service provision }\end{array}$ & $\begin{array}{l}\text { - Considerable private on-plot GI } \\
\text { opportunity } \\
\text { - Dominance of private realm makes } \\
\text { co-ordination of GI challenging } \\
\text { - Reduced land tax per hectare } \\
\text { provides less income for public GI } \\
\text { projects projects/maintenance }\end{array}$ \\
\hline
\end{tabular}

Figure 3. Basic characteristics of four urban fabrics and Gl/BU potential. 
addition to ecosystems services, such projects may be seen as investments. The GI/BU potential of each urban fabric is briefly described below.

Peri-urban areas are the least intensely developed of the urban fabrics. Therefore peri-urban areas have the greatest potential to incorporate well considered GI. Remnant high value ecosystems can be mapped and ideally retained as connected habitat corridors, with new development preferentially located on more degraded patches (cf. McHargian sieve mapping). Similarly, strategically located degraded patches can be identified and enhanced through regenerative design approaches that seek connect isolated fragments into functioning $\mathrm{GI}$ corridors (cf. Lyle, 1996). Regional green infrastructure will need coherent strategic and statutory guidelines to enable any owner or developer to integrate these GI features into their developments.

Automobile fabric with its low-density housing set in gardens, presents considerable possibility for GI, but typically interventions will be smaller scale due to ownership boundary constraints. As a result, it is rare to find extensive areas of private land in the suburbs exhibiting cohesive GI qualities, typically such provision is highly fragmented. In those areas where the urbanised systems of buildings and concrete/asphalt limit opportunities for GI, then $\mathrm{BU}$ should be considered as a way to revive the natural systems. As with peri-urban areas, the GI features will need to be established with owners to enable the full potential of $\mathrm{GI}$ and $\mathrm{BU}$ outcomes.

Transit fabric comprises linear development corridors along mass transit routes, density is high around stations. The linear nature of these corridors lends itself to linear GI where possible, but it will need significantly more $\mathrm{BU}$ to enable its ecological systems to be more fully integrated into the urban fabric. For example, linear green parks, avenues of trees, water sensitive urban design in the form of swales and biofiltration strips can be designed into the street network as 'biophilic streets' (Cabanek, Zingoni de Baro, \& Newman, 2020; Figures 4 and 5). The key is to see that the dense, built environment features can have biophilic features built into them so that water flows, air flows, canopy shading and regional biodiversity are part of the design of any site. This is a multi-skilled planning and design challenge.

Walking urban fabric is the most intensely developed urban fabric. The high density of land use and population leave little room for Gl outside those areas set aside for public realm, i.e., parks and streets. Yet, the high population density makes the importance of $\mathrm{Gl}$ all the greater. Dense urban areas are more vulnerable to climate change impacts such as flash flooding (due to increased impermeable surfaces; Wamsler, Luederitz, \& Brink, 2014), increased urban heat (due to greater thermal mass; Norton et al., 2015), and increased psychological stress due to greater intensity of activity and need to access nature in daily life. The lack of space, which formerly limited GI opportunities may now be overcome through $\mathrm{BU}$ approaches that allow urban nature to be integrated into dense areas. BU thereby can help mitigate these climate change risks (Beatley, 2009) if urban planners can build it into their strategic and statutory systems. Widespread uptake of BU approaches is beginning

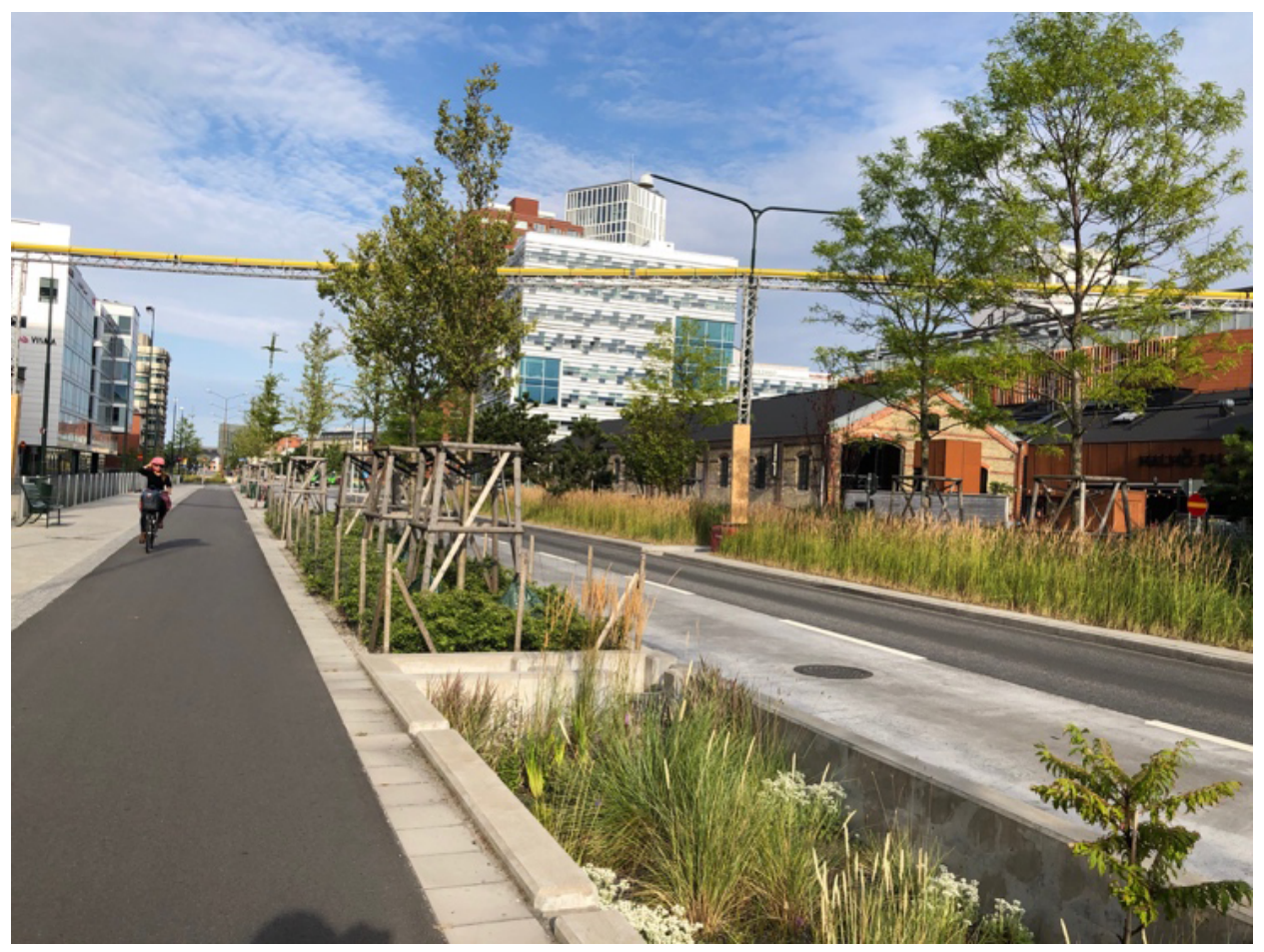

Figure 4. Central Malmö, Sweden: Biophilic streets with water sensitive urban design plus stratified street tree planting. Source: Authors. 


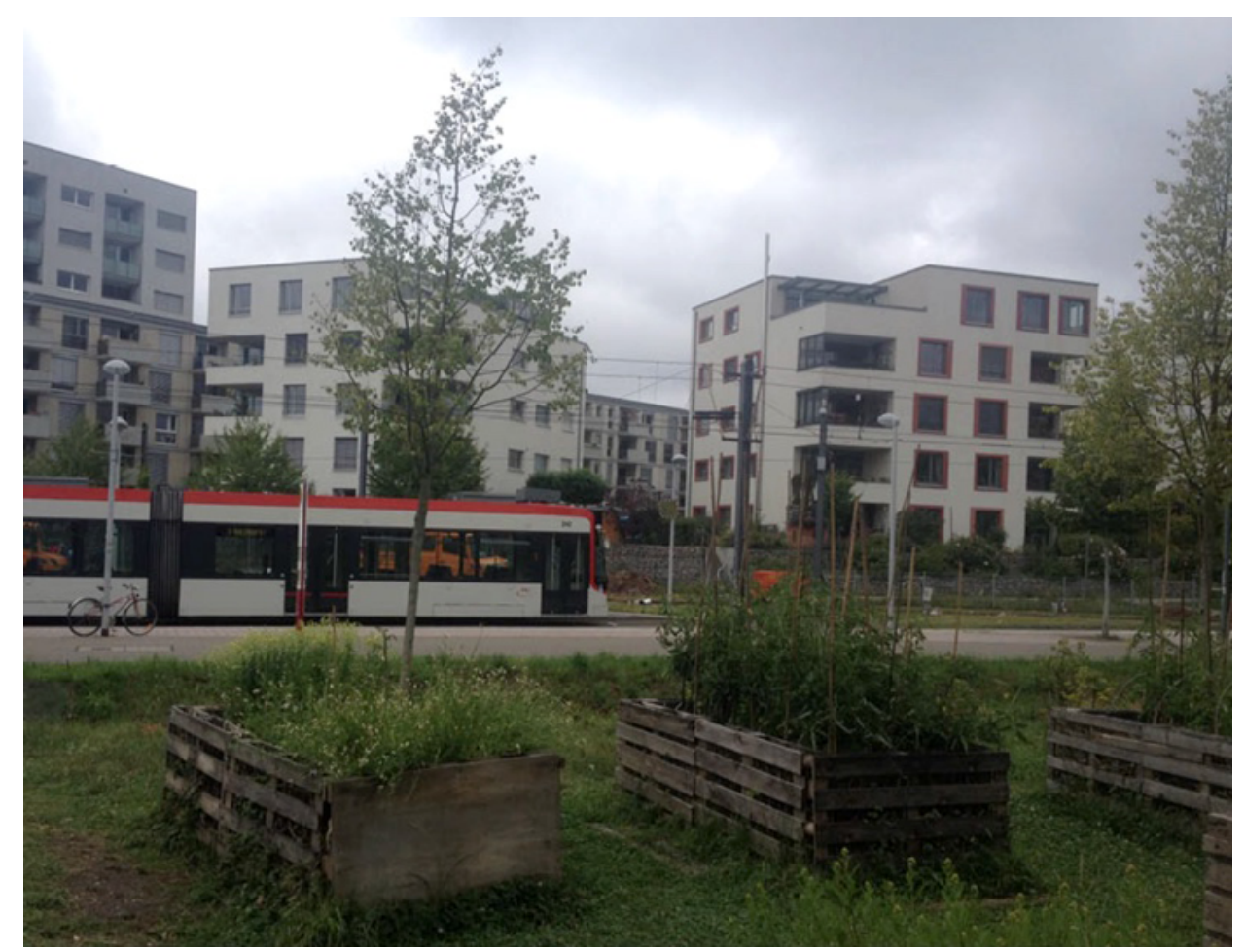

Figure 5. Vauban, Freiburg, Germany, a medium density transit urban fabric serviced by tramline with lawn base to mitigate noise and allow water infiltration surrounded by multiple house-based biophilic features. Source: Authors.

to show how these dense areas can incorporate patches of urban nature, though very few have related their biophilic features to the underlying natural systems that can together integrate a resource efficient and ecological aspects right across the city.

Dense walking urban fabric has less adverse impacts upon ecology due to reduced encroachment upon valuable ecological or arable landscapes (Seto, Güneralp, \& Hutyra, 2012), and the reduced ecological footprint (i.e., eco-efficiency) of dense urban areas (Newman et al., 2017; Thomson \& Newman, 2018b). But making dense urban areas desirable as a place to live is of critical importance. In addition to reducing ecological footprint, $\mathrm{Gl} / \mathrm{BU}$ integration can enhance liveability through improved access to nature.

As cities become denser over time, Gl typically reduces. But planners can mandate increased ecological function as cities increase in density through greater use of BU-as happened in Singapore (Box 1). Using a planning policy known as Landscaping for Urban Spaces and High-Rise programme, Singapore's Urban Redevelopment Authority imposes green space replacement requirements for new buildings in high-density areas to encourage accessible urban greenery (Thomson, Newton, Newman, \& Byrne, 2019). Floor area bonuses are also given to incentivise high quality green space provision in new developments, thus allowing building density to increase as in response to increases in GI/BU density. Thus, McHargian ecological functions can be analysed for even the densest parts of cities and built into the fabric of buildings, urban spaces and roadways to achieve many of the same ecosystem services that would have been there without the built fabric.

\section{Discussion}

\subsection{Garden Cities of the 21st Century}

Ebenezer Howard, who grew up on a farm, argued that garden cities were the key to "restore people to the land" (Clark, 2003, p. 91) his intention was to foster a reconnection between people and nature. In this article we have described the use of urban fabrics as a potential typology to base more appropriate $\mathrm{GI} / \mathrm{BU}$ components into cities. We argue that $\mathrm{GI} / \mathrm{BU}$ responses should respond to the underlying opportunities presented by each urban fabric to create a new breed of garden cities for the 21st century.

It is important to distinguish that what we are describing is about finding space in the city from a planning perspective, because the spatial development patterns of all modern cities we have studied can be categorised into the dominant urban fabrics or variations of them (e.g., Newman et al., 2016). But this space need not be limited to the ground, rather like a forested ecosystem, it can be on vertical surfaces and on different layers that are created by different urban fabrics. However, the GI/BU response remains highly contextual, and the most appropriate intervention must be determined by ecologists, landscape architects and allied professions to ensure a good fit to the bioregion, microclimate, topography, culture, governance and 
Box 1. Singapore's biophilic urbanism tools as the basis of $\mathrm{Gl}$.

Green infrastructure is using ecological systems to enable the management of water, air, waste and open space. In the ecological cities paradigm this means setting aside space to enable trees to cool the urban heat island, daylighting and meandering stormwater flows into creeks from concrete channels and pipes, having natural open spaces that enable biodiversity and human- nature interactions and more. But these opportunities are impossible to introduce into city spaces that are densely constructed because of the need to create agglomeration economies and in recent times to regenerate the resource-consumption of low- density areas.

Singapore was a leader in showing how biophilic urbanism could bring green infrastructure back into dense urban fabric. It did this by creating a strategy, then developing the science of the species and the engineering of how green walls and green roofs could be built in their climate. It then set up demonstrations of all these and also how to close canopies on roads where only small spaces were available for planting, and creating opportunities for creeks to be created from piped stormwater, even where the space was very restrictive. It finally created the manuals that set out how to create all the ecological functions on the actual built urban fabric and regulations that set out how a green floor space ratio could be achieved in the dense central areas of the city.

The result has seen biodiversity regenerating, storm water management made easier and cleaner, urban heat island effect reducing, improved land and rent values in buildings with biophilic facades and roofs, and increased pedestrian activity in areas where nature is more obviously accessible. The health benefits have also increased.

At the same time Singapore has not reduced its development in both central urban regeneration and in new areas where both biophilic strategies and traditional green infrastructure strategies have been used such as in the new Punggol redevelopment corridor.

Sources: Newman (2014) and Blagg (2012).

maintenance strategies and other local considerations. A typological approach using urban fabrics can offer a generalisable guide for finding and allocating space in contested urban areas to facilitate GI/BU integration that could be replicated globally, however, the type of $\mathrm{Gl} / \mathrm{BU}$ intervention will require highly contextualised local responses that see dense urban areas as opportunities just as rich in potential natural habitat as those that are less dense.

\subsection{Greening Cities to Reconnect Citizens to Nature}

Designing $\mathrm{Gl} / \mathrm{BU}$ into cities is important for the increased urban resilience provided by a range of ecosystem services such as urban cooling, stormwater peak flow mitigation, psychological benefits of urban greening and other ecological outcomes; however perhaps more significant is the role that urban $\mathrm{Gl} / \mathrm{BU}$ provides for reconnecting cities and their citizens to the biosphere, whereby citizens become urban stewards of nature (Andersson et al., 2014). Stewardship that involves social networks as well as management and maintenance, that collectively foster the type of ecological mindset that builds interest and agency for a societal transformation toward sustainability. Urban planners tend to focus on housing, transport and economic growth, not protecting ecological and cultivated land, water and biodiversity (Forman \& Wu, 2016). However, placing greater emphasis upon the integration of $\mathrm{Gl} / \mathrm{BU}$ into the various parts of the city can support local planning objectives, while also addressing larger goals of sustainability as set out by the New Urban
Agenda and the Sustainable Development Goals (United Nations General Assembly, 2015).

\subsection{Aligning Other Citizens and Actors}

Because urban planners both shape policy and approve development within cities, they are key actors to enable widespread uptake of urban GI/BU. Planners can develop policies to encourage different $\mathrm{GI}$ and $\mathrm{BU}$ strategies in peri-urban, automobile, transit and walking urban fabrics, but ultimately citizens and other actors (e.g., developers, community leaders, politicians) will be necessary for successful implementation of urban greening projects. Local citizens often act as custodians of their local green space, likewise they will know much more about local ecology and how it can be enhanced than most urban planners, hence citizens should be involved early on in the process of integrating resource efficiency and ecological planning paradigms using $\mathrm{GI}$ and $\mathrm{BU}$ tools.

Context is critically important, as different cities have different needs. Therefore, when considering actions toward meeting the Sustainable Development Goals (particularly Sustainable Development Goal 11 on cities), decisions will need to be considered in terms of the various co-benefits and trade-offs (Akuraju, Pradhan, Haase, Kropp, \& Rybski, 2020). Context matters, not only between different cities in a particular ecological region where partnerships in GI planning across multiple boundaries will be required, but also in different parts of a city where the use of urban fabrics as a planning lens is useful to help inform policy choices. Partnerships across local 
governments will be essential to use $\mathrm{GI}$ and $\mathrm{BU}$ tools across the whole city. In dense walking urban fabric, new biophilic strategies will be most appropriate as they will allow, and support, retention of those benefits that are afforded by high-density, compact urban areas. By contrast, automobile urban fabric will benefit from more traditional $\mathrm{Gl}$ approaches that can be accommodated in less intensely developed urban fabric. However, as outlined above, both sets of tools overlap and will be needed to enable local ecology and more system-wide ecology to be enhanced.

Presenting $\mathrm{Gl} / \mathrm{BU}$ choices as a typology grounded in urban fabrics opens up a range of much more focussed discussion points based upon trade-offs and co-benefits that can be used to inform deliberative processes with citizens, politicians and other actors. But it is important to also note that just having a strategy for accommodating $\mathrm{Gl} / \mathrm{BU}$ within a city will not be sufficient without having a clear strategic McHargian concept plan across the city/region, and without considering the essential alignment of agencies, organisations, and citizens who ideally will co-ordinate to ensure clarity around the long-term management and maintenance of new ecological assets. For example, Pincetl's (2010) detailed case study on the Los Angeles million tree initiative offers a glimpse into some of the actor alignment co-ordination challenges to be overcome when attempting to implement novel, large scale, centralised (i.e., government led) urban tree greening programs.

\section{Conclusions}

This article describes how the two apparently conflicting sustainable planning paradigms of resource efficient cities (pro-density) and ecological cities (anti-density) can be resolved. The cause of the conflict was finding space to maximise urban nature, but density need not be seen as a barrier now to integrating GI, rather with new scientific and engineering approaches nature can be integrated into any urban area. A lack of available space in dense areas can be overcome by BU tools that allow nature to be integrated on or over buildings and infrastructure e.g., biophilic streets, green roofs and green walls. However, to maximise urban nature requires urban planners to consider what GI/BU components are appropriate to the prevailing development pattern. Recognising that different parts of the city have different potential can assist with decision support and policy creation for a more nuanced GI/BU response. A typological classification based upon the dominant (or expected) urban fabric can inform planning policy and support the work of landscape architects, civil engineers, developers and related actors to tailor appropriate GI/BU tools. This in turn will help operationalise ecological and resource efficient cities that could lead to a flourishing of garden cities in the 21st century.

This draws upon and embraces aspects of the garden city as envisaged by Howard over 100 years ago- aspects of which are as relevant now as ever but now includes new science and technology as well as new understandings of how cities work that can help bring these old principles to life. There are numerous reasons for why our cities need this combination of the old and new, including:

- The climate adaptation and resilience benefits of ecosystems services are now a critical agenda for cities in the 21st century;

- The psychological benefits of biophilic environments to enhance quality of life and mental wellbeing, particularly within megacities where large conurbations can make it difficult for citizens to access nature, and perhaps most importantly;

- Re-introducing nature to cities to provide opportunity for citizens to engage with nature, thus increasing their eco-literacy.

The drivers are there for planning policy revision, just as they were when Howard's garden city concept took hold within the professions; but even with policies in place, implementing such a vision will require many actors from science and urban planning working collaboratively together:

- Botanists, ecologists, hydrologists and related scientific expertise, plus the façade engineers who can help to identify the most appropriate solution for the given bioregion and the particular urban fabric, and;

- Designers to conceive and document localised urban interventions, plus the municipal support or citizen collectives to maintain and manage urban $\mathrm{Gl} / \mathrm{BU}$.

While multi- and trans-disciplinary approaches will be needed to effectively deliver integrated resource efficient and ecological cities, urban planning is the only profession capable of strategically and systematically providing the conditions to embed GI into all parts of the city. This will likely prove challenging for many traditionally trained urban planners, as it falls outside the usual scope of conventional planning practice; however, the combined mitigation, adaptation and psychosocial benefits of incorporating $\mathrm{Gl} / \mathrm{BU}$ into all parts of the city justifies the efforts required to change policies to help our cities rise to meet the grand challenges of the Anthropocene as well as the small challenges of creating competitive and attractive urban economies and communities.

Transformation of urban systems toward resource efficient energy, water and waste systems is central to the future of the planet, but equally important is an ecological approach to maximise nature within cities. These agendas may be perceived by some as conflicting. But just because resource efficient approaches to materials and resources benefit from a compact urban city agenda, this does not mean ecological systems must be displaced 
within the city. Rather, as this article shows, urban fabrics offer guidance on how GI may be integrated by using BU approaches in dense urban regeneration projects, and in traditional ways in low-density areas. Thus, reducing land take and resource use, while simultaneously regenerating the local ecology.

\section{Acknowledgments}

The authors thank the three anonymous reviewers for suggestions that helped improve the article. Giles Thomson would like to acknowledge financial support through the Knowledge Foundation (KK-stiftelsen) in Sweden.

\section{Conflict of Interests}

The authors declare no conflict of interests.

\section{References}

Akuraju, V., Pradhan, P., Haase, D., Kropp, J. P., \& Rybski, D. (2020). Relating SDG11 indicators and urban scaling: An exploratory study. Sustainable Cities and Society, 52. https://doi.org/10.1016/j.scs.2019.101853

Andersson, E., Barthel, S., Borgström, S., Colding, J., Elmqvist, T., Folke, C., \& Gren, Å. (2014). Reconnecting cities to the biosphere: Stewardship of green infrastructure and urban ecosystem services. Ambio, 43(4), 445-453. https://doi.org/10.1007/ s13280-014-0506-y

Beatley, T. (2009). Biophilic urbanism: Inviting nature back to our communities and into our lives. William \& Mary Environmental Law \& Policy Review, 34(1), 209-238.

Beatley, T. (2011). Biophilic cities: Integrating nature into urban design and planning. Washington, DC: Island Press.

Beatley, T., \& Newman, P. (2013). Biophilic cities are sustainable, resilient cities. Sustainability, 5(8), 3328-3345. https://doi.org/10.3390/su5083328

Blagg, L. (2012, May 7). Singapore: Biophilic city [Video file]. Retrieved from https://www.youtube.com/ watch?v=XMWOu9xIM_k\&ab_channel=lindablagg

Breheny, M. (1997). Urban compaction: Feasible and acceptable? Cities, 14(4), 209-217. https:// doi.org/10.1016/s0264-2751(97)00005-x

Brink, E., Aalders, T., Ádám, D., Feller, R., Henselek, Y., Hoffmann, A., . . . Wamsler, C. (2016). Cascades of green: A review of ecosystem-based adaptation in urban areas. Global Environmental Change, 36, 111-123. https://doi.org/10.1016/j.gloenvcha.2015. 11.003

Cabanek, A., Zingoni de Baro, M. E., \& Newman, P. (2020). Biophilic streets: A design framework for creating multiple urban benefits. Sustainable Earth, 3(1). https://sustainableearth.biomedcentral. com/articles/10.1186/s42055-020-00027-0
Calthorpe, P. (2010). Urbanism in the age of climate change. Washington, DC: Island Press.

Clark, B. (2003). Ebenezer Howard and the marriage of town and country. Organization and Environment, 16(1), 87-97. https://doi.org/10.1177/10860 26602250258

Colding, J., \& Barthel, S. (2013). The potential of "Urban Green Commons" in the resilience building of cities. Ecological Economics, 86, 156-166. https://doi.org/ 10.1016/j.ecolecon.2012.10.016

Creutzig, F., Roy, J., Lamb, W., Azeveno, I., de Bruine, W., Dalkmann, H., ... Weber, E. (2018). Towards demandside solutions for mitigating climate change. Nature Climate Change, 8(4), 268-271.

Ding, L. (2019). Cooling our cities: A decision support tool for reducing urban heat. Sydney: CRC Low Carbon Living. Retrieved from http://www. lowcarbonlivingcrc.com.au/sites/all/files/ publications_file_attachments/20170522_rp2023_ fact_sheet.pdf

European Commission. (2013). Green infrastructure (GI): Enhancing Europe's natural capital. Brussels: European Commission.

Folke, C., Jansson, Å., Larsson, J., \& Costanza, R. (1997). Ecosystem appropriation by cities. Ambio, 26(3), 167-172. https://doi.org/10.2307/4314576

Forman, R. T. T., \& Wu, J. (2016). Where to put the next billion people. Nature, 537, 608-611. https:// doi.org/10.1038/537608a

Gao, Y., Newman, P., \& Webster, P. (2015). Transport transitions in Beijing: From bikes to automobiles to trains. The Journal of Sustainable Mobility, 2(1), 11-26.

Geddes, P. (1915). Cities in evolution: An introduction to the town planning movement and to the study of civics. London: Williams \& Norgate. https://doi.org/ $10.2307 / 3159745$

Gehl, J. (2010). Cities for people. Washington, DC: Island Press.

Girardet, H. (2010). Regenerative cities. World Future Council. Retrieved from https://www.worldfuture council.org/regenerative-cities

Girardet, H. (2015). Creating regenerative cities. Abingdon: Routledge.

Grimm, N. B., Grimm, N. B., Faeth, S. H., Golubiewski, N. E., Redman, C. L., Wu, J., . . Briggs, J. M. (2008). Global change and the ecology of cities. Science, 756. https://doi.org/10.1126/science.1150195

Hall, T. (2007). Where have all the gardens gone? An investigation into the disappearance of back yards in the newer Australian suburb (Research Paper No. 13). Brisbane: Urban Research Program.

Hansen, R., Frantzeskaki, N., McPhearson, T., Rall, E., Kabisch, N., Kaczorowska, A., . . . Pauleit, S. (2015). The uptake of the ecosystem services concept in planning discourses of European and American cities. Ecosystem Services, 12, 228-246. https://doi.org/ 10.1016/j.ecoser.2014.11.013 
Hes, D., \& du Plessis, C. (2014). Designing for hope: Pathways to regenerative sustainability. New York, NY: Taylor \& Francis.

Howard, E. (1902). Garden cities of tomorrow. London: Swan Sonnenschein \& Company, Limited.

Intergovernmental Panel on Climate Change. (2018). Global warming of $1.5^{\circ} \mathrm{C}$. Geneva: Intergovernmental Panel on Climate Change. Retrieved from http:// www.ipcc.ch/report/sr15

Kellert, S. R. (2012). Building for life: Designing and understanding the human-nature connection. Washington, DC: Island Press.

Kostoff, B. (1991). The city shaped: Urban patterns and meanings through history. London: Thames and Hudson.

Lo, A. Y. (2016). Small is green? Urban form and sustainable consumption in selected OECD metropolitan areas. Land Use Policy, 54, 212-220. https://doi.org/ 10.1016/j.landusepol.2016.02.014

Lyle, J. T. (1996). Regenerative design for sustainable development. New York, NY: Wiley.

Mang, P., \& Reed, B. (2012). Designing from place: A regenerative framework and methodology. Building Research \& Information, 40(1), 23-38. https://doi. org/10.1080/09613218.2012.621341

Marcus, L., Pont, M. B., \& Barthel, S. (2019). Towards a socio-ecological spatial morphology: Integrating elements of urban morphology and landscape ecology. Urban Morphology, 23, 115-124.

Matan, A., \& Newman, P. (2016). People cities: The life and legacy of Jan Gehl. Washington, DC: Island Press.

Mcdonald, R., Beatley, T., \& Elmqvist, T. (2018). The green soul of the concrete jungle: The urban century, the urban psychological penalty, and the role of nature. Sustainable Earth. https://sustainableearth. biomedcentral.com/articles/10.1186/s42055-0180002-5

McDonald, R., Kroeger, T., Boucher, T., Longzhu, W., Salem, R., Adams, J., . . . Garg, S. (2016). Planting healthy air: A global analysis of the role of urban trees in addressing particulate matter pollution and extreme heat. Arlington, VA: Nature.

McHarg, I. L. (1969). Design with nature. New York, NY: The Natural History Press.

McKinney, M. L. (2006). Urbanization as a major cause of biotic homogenization. Biological Conservation, 127(3), 247-260. https://doi.org/10.1016/j.biocon. 2005.09.005

MEA. (2005). Millenium ecosystem assessment: Ecosystems and human well-being: Synthesis. Washington, DC: MEA. https://doi.org/10.1016/B978-0-12809665-9.09206-5

Mumford, L. (1961). The city in history. London: Penguin.

Neuman, M. (2005). The compact city fallacy. Journal of Planning Education and Research, 25, 11-26. https:// doi.org/10.1177/0739456X04270466

Newman, P. (2014). Biophilic urbanism: A case study on Singapore. Australian Planner, 51(1), 47-65. https:// doi.org/10.1080/07293682.2013.790832

Newman, P. (2020). Cool planning: How urban planning can mainstream responses to climate change. Cities, 103, 1-14. https://doi.org/10.1016/j.cities. 2020.102651

Newman, P., Beatley, T., \& Boyer, H. (2017). Resilient cities, second edition: Overcoming fossil fuel dependence. Washington DC: Island Press.

Newman, P., \& Jennings, I. (2008). Cities as sustainable ecosystems: Principles and practices. Washington, DC: Island Press.

Newman, P., \& Kenworthy, J. (1989). Cities and automobile dependence: An international sourcebook. Aldershot: Gower Publishing Company.

Newman, P., \& Kenworthy, J. (1999). Sustainability and cities: Overcoming automobile dependence. Washington, DC: Island Press.

Newman, P., \& Kenworthy, J. (2015). The end of automobile dependence: How cities are moving beyond carbased planning. Washington, DC: Island Press.

Newman, P., Kosonen, L., \& Kenworthy, J. (2016). The theory of urban fabrics: Planning the walking, transit and automobile cities for reduced automobile dependence. Town Planning Reviews, 87(4), 429-458. https://doi.org/10.3828/tpr.2016.28

Newman, P., Thomson, G., Helminen, V., Kosonen, L., \& Terämä, E. (2019). Sustainable cities: How urban fabrics theory can help sustainable development. Helskini: Reports of the Finnish Environment Institute.

Newton, P., \& Glackin, S. (2014). Understanding infill: Towards new policy and practice for urban regeneration in the established suburbs of Australia's cities. Urban Policy and Research, 32(2), 121-143. https:// doi.org/10.1080/08111146.2013.877389

Newton, P., \& Thomson, G. (2016). Urban regeneration in Australia. In P. Roberts, H. Sykes, \& R. Granger (Eds.), Urban regeneration (2nd ed., pp. 228-313). London: SAGE.

Norton, B. A., Coutts, A. M., Livesley, S. J., Harris, R. J., Hunter, A. M., \& Williams, N. S. G. (2015). Planning for cooler cities: A framework to prioritise green infrastructure to mitigate high temperatures in urban landscapes. Landscape and Urban Planning, 134, 127-138. https://doi.org/10.1016/ j.landurbplan.2014.10.018

Pauleit, S., Zölch, T., Hansen, R., Randrup, T., \& Konijnendijk van den Bosch, C. (2017). Nature-based solutions and climate change: Four shades of green. In N. Kabisch, H. Korn, J. Stadler, \& A. Bonn (Eds.), Nature-based solutions to climate change adaptation in urban areas: Linkages between science, policy and practice (pp. 29-51). Cham: Springer. https:// doi.org/10.1007/978-3-319-56091-5

Pincetl, S. (2010). Implementing municipal tree planting: Los Angeles million-tree initiative. Environmental Management, 45(2), 227-238. https://doi.org/ 10.1007/s00267-009-9412-7

Rees, W., \& Wackernagel, M. (2008). Urban ecological 
footprints: Why cities cannot be sustainable and why they are a key to sustainability. Urban Ecology: An International Perspective on the Interaction Between Humans and Nature, 16, 537-555. https://doi.org/ 10.1007/978-0-387-73412-5_35

Roberts, P., Sykes, H., \& Granger, R. (2016). Urban regeneration. London: SAGE.

Samuelsson, K., Colding, J., \& Barthel, S. (2019). Urban resilience at eye level: Spatial analysis of empirically defined experiential landscapes Landscape and Urban Planning Urban resilience at eye level: Spatial analysis of empirically defined experiential landscapes. Landscape and Urban Planning, 187, 70-80. https://doi.org/10.1016/j.landurbplan.2019.03.015

Seto, K., Dhakal, S., Bigio, A., Blanco, H., Delgardo, G., Dewar, D., . . . Ramaswami, A. (2014). Human settlements, infrastructure, and spatial planning. In $\mathrm{O}$. Edenhofer, R. Pichs-Madruga, Y. Sokona, E. Farahani, S. Kadner, K. Seyboth, . . . J. Minx (Eds.), Climate change 2014: Mitigation of climate change. Contribution of working group III to the fifth assessment report of the Intergovernmental Panel on Climate Change (pp. 1083-1141). Cambridge and New York, NY: Cambridge University Press.

Seto, K., Güneralp, B., \& Hutyra, L. (2012). Global forecasts of urban expansion to 2030 and direct impacts on biodiversity and carbon pools. Proceedings of the National Academy of Sciences of the United States of America, 109(40), 16083-16088. https://doi.org/ 10.1073/pnas.1211658109

Soderlund, J., \& Newman, P. (2015). Biophilic architecture: A review of the rationale and outcomes. AIMS Environmental Science, 2(4), 950-969. https://doi. org/10.3934/environsci.2015.4.950

Soga, M., \& Gaston, K. J. (2016). Extinction of experience: The loss of human-nature interactions. Frontiers in Ecology and the Environment, 14(2), 94-101. https://doi.org/10.1002/fee.1225

Thomson, G., \& Newman, P. (2016). Geoengineering in the anthropocene through regenerative urbanism. Geosciences, 6(4). https://doi.org/10.3390/ geosciences6040046

Thomson, G., \& Newman, P. (2017). Infrastructure for infill development. In S. Rowley, R. Ong, \& A. James (Eds.), Perth's infill housing future: Delivering innovative and sustainable housing (pp. 145-176). Perth: Curtin University.

Thomson, G., \& Newman, P. (2018a). Cities and the anthropocene: Urban governance for the new era of regenerative cities. Urban Studies, 57(7). https:// doi.org/10.1177/0042098018779769

Thomson, G., \& Newman, P. (2018b). Urban fabrics and urban metabolism: From sustainable to regenerative cities. Resources, Conservation and Recycling, 132, 218-229. https://doi.org/10.1016/j.resconrec.2017. 01.010

Thomson, G., Newton, P., Newman, P., \& Byrne, J. (2019). Guide to low carbon precincts. Sydney: Low Carbon Living CRC.

United Nations. (2017). New Urban Agenda. Quito: United Nations.

United Nations General Assembly. (2015). Transforming our world: The 2030 agenda for sustainable development. New York, NY: United Nations. https://doi.org/ 10.1007/s13398-014-0173-7.2

Unwin, R. (1912). Nothing gained by overcrowding! How the garden city type of development may benefit both owner and occupier. London: P.S. King \& Son.

Urry, J. (2004). The system of automobility. Theory, Culture and Society, 21(4/5), 25-39.

Wamsler, C., Luederitz, C., \& Brink, E. (2014). Local levers for change: Mainstreaming ecosystem-based adaptation into municipal planning to foster sustainability transitions. Global Environmental Change, 29, 189-201. https://doi.org/10.1016/j.gloenvcha.2014. 09.008

Wilson, E. (1984). Biophilia. Cambridge, MA: Harvard University Press.

\section{About the Authors}

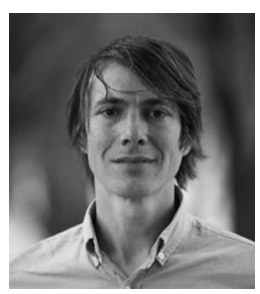

Giles Thomson, PhD, is an Urban Planner and Researcher who has worked on large scale urban planning projects in the UK, China and Australia. Giles' research focus is urban sustainability transformations. He is currently an Associate Senior Lecturer in the Department for Strategic Sustainable Development at Blekinge Institute for Technology, Sweden.

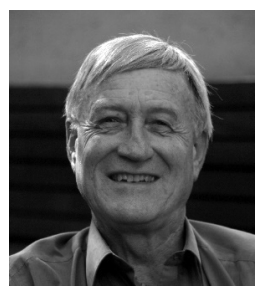

Peter Newman is the Professor of Sustainability at Curtin University in Perth, Australia. Peter has written 20 books and over 350 papers on sustainable cities and has worked to deliver his ideas in all levels of government. He is the Co-Ordinating Lead Author for the UN's IPCC on Transport. In 2014 he was awarded an Order of Australia for his contributions to urban design and sustainable transport. In 2018/2019 he was the WA Scientist of the Year. 